\title{
The Effect of $\mathrm{HbA}_{1 \mathrm{c}}$ Variability as a Risk Measure for Microangiopathy in Type 1 Diabetes Mellitus
}

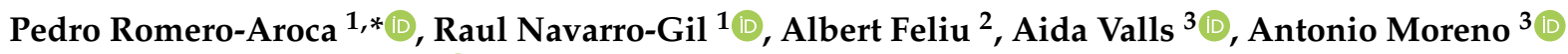 \\ and Marc Baget-Bernaldiz ${ }^{1}$ (D) \\ 1 Ophthalmology Service, University Hospital Sant Joan, Institut de Investigacio Sanitaria Pere Virgili (IISPV), \\ Universitat Rovira \& Virgili, 43204 Reus, Spain; raul_navarro_gil@hotmail.com (R.N.-G.); \\ mbaget@gmail.com (M.B.-B.) \\ 2 Pediatric Service, University Hospital Sant Joan, Institut de Investigacio Sanitaria Pere Virgili (IISPV), \\ Universitat Rovira \& Virgili, 43204 Reus, Spain; albert.feliu.rovira@gmail.com \\ 3 Departament d'Enginyeria Informàtica I Matemàtiques, Escola Tècnica Superior d'Enginyeria, Universitat \\ Rovira \& Virgili, ITAKA-Intelligent Technologies for Advanced Knowledge Acquisition, \\ 43204 Tarragona, Spain; aida.valls@urv.cat (A.V.); antonio.moreno@urv.cat (A.M.) \\ * Correspondence: romeropere@gmail.com; Tel.: +34-977310300; Fax: +34-97732375
}

Citation: Romero-Aroca, P.;

Navarro-Gil, R.; Feliu, A.; Valls, A.;

Moreno, A.; Baget-Bernaldiz, M. The Effect of $\mathrm{HbA}_{1 \mathrm{c}}$ Variability as a Risk Measure for Microangiopathy in Type 1 Diabetes Mellitus. Diagnostics 2021, 11, 1151. https://doi.org/10.3390/ diagnostics11071151

Academic Editor: Ramin Khoramnia

Received: 16 May 2021

Accepted: 22 June 2021

Published: 24 June 2021

Publisher's Note: MDPI stays neutral with regard to jurisdictional claims in published maps and institutional affiliations.

Copyright: (c) 2021 by the authors. Licensee MDPI, Basel, Switzerland. This article is an open access article distributed under the terms and conditions of the Creative Commons Attribution (CC BY) license (https:// creativecommons.org/licenses/by/ $4.0 /)$.

\begin{abstract}
Background: To measure the relationship between variability in $\mathrm{HbA}_{1 \mathrm{c}}$ and microalbuminuria (MA) and diabetic retinopathy (DR) in the long term. Methods: A prospective case-series study, was conducted on 366 Type 1 Diabetes Mellitus patients with normoalbuminuria and without diabetic retinopathy at inclusion. The cohort was followed for a period of 12 years. The Cox survival analysis was used for the multivariate statistical study. The effect of variability in microangiopathy (retinopathy and nephropathy) was evaluated by calculating the standard deviation of $\mathrm{HbA}_{1 \mathrm{c}}$ (SD$\left.\mathrm{HbA}_{1 \mathrm{c}}\right)$, the coefficient of variation of $\mathrm{HbA}_{1 \mathrm{c}}\left(\mathrm{CV}-\mathrm{HbA}_{1 \mathrm{c}}\right)$, average real variability $\left(\mathrm{ARV}-\mathrm{Hb} \mathrm{A}_{1 \mathrm{c}}\right)$ and variability irrespective of the mean $\left(\mathrm{VIM}-\mathrm{HbA}_{1 \mathrm{c}}\right.$ ) adjusted for the other known variables. Results: A total of 106 patients developed diabetic retinopathy (29\%) and 73 microalbuminuria (19.9\%). Overt diabetic nephropathy, by our definition, affected only five patients (1.36\%). Statistical results show that the current age, mean $\mathrm{HbA}_{1 \mathrm{c}}$, $\mathrm{SD}-\mathrm{HbA}_{1 \mathrm{c}}$ and $\mathrm{ARV}-\mathrm{Hb} \mathrm{A}_{1 \mathrm{c}}$ are significant in the development of diabetic retinopathy. Microalbuminuria was significant for current age, mean $\mathrm{HbA}_{1 c}, \mathrm{CV}-\mathrm{Hb} \mathrm{A}_{1 \mathrm{c}}$ and $\mathrm{ARV}-\mathrm{HbA}_{1 \mathrm{c}}$. Conclusions: By measuring the variability in $\mathrm{HbA}_{1 \mathrm{c}}$, we can use $\mathrm{SD}-\mathrm{HbA}_{1 \mathrm{c}}$ and $\mathrm{ARV}-\mathrm{HbA}_{1 \mathrm{c}}$ as possible targets for judging which patients are at risk of developing DR and MA, and $\mathrm{CV}-\mathrm{HbA}_{1 \mathrm{c}}$ as the target for severe DR.
\end{abstract}

Keywords: $\mathrm{HbA}_{1 \mathrm{c}}$ variability; coefficient of variation of $\mathrm{HbA}_{1 \mathrm{c}}$; diabetic retinopathy; severity of diabetic retinopathy

\section{Introduction}

It is estimated that 415 million people worldwide were living with some form of diabetes in 2015 [1] and that number has been predicted to rise to around 640 million by 2040 [2]. It has become a chronic disease with several complications. Diabetes Mellitus (DM) is classified as Type 1 Diabetes (T1DM), Type 2 Diabetes (T2DM), gestational diabetes (GDM), monogenic diabetes (MODY) and secondary diabetes [3]. There is a current trend towards children developing T1DM and more than half a million children are estimated to be currently living with the disease.

Diabetes Mellitus (DM) is one of the main causes of morbidity and mortality in the developed world. Microangiopathy affects the retinal vessels and leads to diabetic retinopathy (DR), which is a major case of visual loss worldwide [4]. Furthermore, the effect on kidneys leads to overt nephropathy (ON). Currently, we know that an early form of kidney damage in DM1 patients is microalbuminuria (MA), which is an early-stage diabetic nephropathy. 
It is well established that chronic hyperglycaemia is one of the main risk factors for microangiopathy and can be assessed by determining $\mathrm{HbA}_{1 \mathrm{c}}$ levels [5].

However, in clinical practice, we observe that patients with good $\mathrm{HbA}_{1 \mathrm{c}}$ levels can still develop DR or nephropathy. Some authors pointed to the likelihood of another factor, independent from the updated mean $\mathrm{HbA}_{1 \mathrm{c}}$, that might contribute to the risk of developing complications, suggested as glycaemic variability (GV) [6]. Initial studies attempted to evaluate the intra-day and inter-day changes in glycaemia, but with no success [7-9]. Since then, studies of long-term changes in glycaemia, measured by changes in $\mathrm{HbA}_{1 \mathrm{c}}$, have been successful [10-16]. Long term changes in glycaemia can currently be calculated by measuring the mean and standard deviation of $\mathrm{HbA}_{1 \mathrm{c}}\left(\mathrm{SD}-\mathrm{HbA}_{1 \mathrm{c}}\right)$, the coefficient of variation of $\mathrm{HbA}_{1 \mathrm{c}}\left(\mathrm{CV}-\mathrm{HbA}_{1 \mathrm{c}}\right)$, the average real variability $\left(\mathrm{ARV}-\mathrm{Hb} \mathrm{A}_{1 \mathrm{c}}\right)$ and the variability independent of the mean $\left(\mathrm{VIM}-\mathrm{HbA}_{1 \mathrm{c}}\right)[17,18]$.

The aim of present study was to measure the relationship between diabetic retinopathy and diabetic nephropathy development according to variability in $\mathrm{HbA}_{1 c}$, measured by the following parameters: mean, SD-HbA $\mathrm{Ac}_{1 \mathrm{c}}, \mathrm{CV}-\mathrm{HbA}_{1 \mathrm{c}}, \mathrm{AVR}-\mathrm{HbA}_{1 \mathrm{c}}$ and $\mathrm{VIM}-\mathrm{HbA}_{1 \mathrm{c}}$.

\section{Subjects}

2.1. Setting

The reference population in our area is 247,174 . The total number of DM patients registered with our Health Care Area (University Hospital Saint Joan, Tarragona, Spain) is 17,792 (7.1\%). Our DR screening programme has been ongoing since 2007, when we offered a retinography annually to our T1DM patients. The screening programme is described more completely elsewhere $[19,20]$.

\subsection{Design}

We carried out a prospective, case series study of 366 T1DM patients who were not part of the screening programme on 1 January 2007 and who did not initially have DR or MA.

Inclusion criteria: T1DM patients had to have a minimum of eight prior $\mathrm{HbA}_{1 \mathrm{c}}$ measures.

Exclusion criteria: patients with T2DM, GDM or other specific types of diabetes due to other causes, e.g., monogenic diabetes syndromes (such as neonatal diabetes and MODY), diseases of the exocrine pancreas (such as cystic fibrosis and pancreatitis), and drug-or chemical-induced diabetes (such as with glucocorticoid use in the treatment of HIV/AIDS, or after organ transplantation).

\section{Material and Methods}

A total of 366 patients with T1DM, as diagnosed by endocrinologists, were followed between 1 January 2007 and 31 December 2020. The retinographies were taken under mydriasis according to the Joslin Vision Network with 3 fields of $45^{\text {a }}$ (macula-focused; nasal; temporal superior) using a Topcon NW400 retinal camera, [21]. All patients were submitted to one retinography per year.

The DR was diagnosed by reading the retinographies by a retinal expert ophthalmologist, and diagnosis was determined when microaneurysms were present in the fundus retinography. Classification was conducted according to the International Council of Ophthalmology, ICO [22] as (i) mild DR with only microaneurysms, (ii) moderate DR (microaneurysms, hard exudates, haemorrhages and venous abnormalities), (iii) severe DR (the above together with one of the following: $>20$ haemorrhages in each quadrant, venous anomalies defined in 2 quadrants, intra-retinal microvascular abnormalities in 1 quadrant, no signs of proliferation, and (iv) proliferative DR, defined by a presence of neovascularization.

In patients diagnosed with diabetic retinopathy, a complete ophthalmological examination was performed that included visual acuity, anterior segment biomicroscopy and optical coherence tomography (OCT). 
General Practitioners and endocrinologists provided information on the duration of DM, arterial hypertension and body mass index (BMI).

\subsection{Laboratory Analysis}

A venous blood sample was obtained after fasting and serum and EDTA plasma were stored at $-80{ }^{\circ} \mathrm{C}$ until measurements were taken.

Levels of glycosylated haemoglobin $\left(\mathrm{HbA}_{1 \mathrm{c}}\right)$ [19] were measured at least twice a year, as recommended by the American Diabetes Association, during the 12-year follow-up and a mean of all values was applied to the study. Glycaemia was controlled according to the European Diabetes Policy Group, and the standards of medical care in diabetes of the American Association of Diabetes [23,24]. The $\mathrm{HbA}_{1 \mathrm{c}}$ values were obtained after blood extraction and were standardized according to the DCCT reference range $(20.7-42.6 \mathrm{mmol} / \mathrm{mol})$ [25]. The mean $\mathrm{HbA}_{1 \mathrm{c}}$ (Mean) values were calculated after a minimum of $8 \mathrm{HbA}_{1 \mathrm{c}}$ determinations per patient in the four years prior to DR diagnosis or the last visit.

The urine analysis was performed at least once per year and the presence of MA, defined as an increased albumin excretion of $30-300 \mathrm{mg} / \mathrm{g}(30-300 \mathrm{mg}$ of albumin $/ 24 \mathrm{~h}$ or $20-200 \mu \mathrm{g} / \mathrm{min}$ of albumin) in two out of three tests repeated at intervals of 3-6 months, as well as exclusion conditions that invalidate the test. Following a diagnosis of MA, there was repeat testing over a period of 3-4 months. Presence of overt nephropathy, defined as both clinical albuminuria or overt nephropathy by the American Diabetes Association, corresponding to protein excretion $>300 \mathrm{mg} / 24 \mathrm{~h}$. Glomerular filtration rate (eGFR), as measured by the chronic kidney disease epidemiology collaboration equation CKD-EPI, was estimated on the same urine collection. The microalbuminuria development was defined as MA onset during the studied period.

Finally, we determined the serum levels of the following: HDL cholesterol, LDL cholesterol and triglycerides. In the statistical analysis, we classified patients into normal or the following risk levels: HDL cholesterol normal value $\geq 1.10 \mathrm{mg} / \mathrm{dL}$, LDL cholesterol normal value $\leq 2 \mathrm{mg} / \mathrm{dL}$. Triglycerides normal value $\leq 1.70 \mathrm{mg} / \mathrm{dL}$, at least one year determination of lipid profile was performed.

\subsection{Variability of $\mathrm{Hb}_{1 c}$ Calculation}

Variability of $\mathrm{HbA}_{1 \mathrm{c}}$ was measured by four different values:

1. The standard deviation of the mean $\mathrm{HbA}_{1 \mathrm{c}}\left(\mathrm{SD}-\mathrm{HbA}_{1 \mathrm{c}}\right)$.

2. The average real variability $\left(\mathrm{ARV}-\mathrm{HbA}_{1 \mathrm{c}}\right)$ is the average of the absolute differences between consecutive $\mathrm{HbA}_{1 \mathrm{c}}$ measurements.

3. The coefficient of variation of $\mathrm{HbA}_{1 \mathrm{c}},\left(\mathrm{CV}-\mathrm{HbA}_{1 \mathrm{c}}\right)$ applying the following formula, [12] $\mathrm{CV}-\mathrm{HbA}_{1 \mathrm{c}}=\mathrm{SD}-\mathrm{HbA}_{1 \mathrm{c}} /$ Mean $\mathrm{HbA}_{1 \mathrm{c}}$

4. The variability independent of the mean $\left(\mathrm{VIM}-\mathrm{HbA}_{1 \mathrm{c}}\right)$ is a transformation of the standard deviation, which is not correlated with mean $\mathrm{HbA}_{1 \mathrm{c}}$ and is calculated as follows [26]:

$$
\text { VIM-HBA }{ }_{1 c}=\mathrm{k} x \text { tandard deviation of } \mathrm{HbA}_{1 \mathrm{c}}\left(\mathrm{SD}-\mathrm{Hb} \mathrm{A}_{1 \mathrm{c}}\right) / \text { Mean }\left(\mathrm{HbA}_{1 \mathrm{c}}\right)^{\mathrm{x}}
$$

where $x$ is calculated from fitting a power model: SD-HbA $1 \mathrm{c}=$ constant $x$ Mean $\mathrm{HbA}_{1 \mathrm{c}} \times$ and $\mathrm{k}=$ Mean $\left(\text { Mean } \mathrm{HbA}_{1 \mathrm{c}}\right)^{\mathrm{x}}$.

\subsection{Statistical Methods}

Dependent variables were DR and MA, and the independent variables were current age, gender, duration of $\mathrm{DM}$, arterial hypertension, body mass index (BMI), the mean$\mathrm{HbA}_{1 \mathrm{c}}$, lipid profile (determining LDL cholesterol, HDL cholesterol and triglycerides), renal status (estimated glomerular filtration rate (eGFR) as measured by the chronic kidney disease epidemiology collaboration equation CKD-EPI).

Variability of $\mathrm{HbA}_{1 \mathrm{c}}$ was measured by the following parameters: SD-HbA $\mathrm{Ac}_{1 \mathrm{c}}, \mathrm{CV}-$ $\mathrm{HbA}_{1 \mathrm{c}}, \mathrm{ARV}-\mathrm{HbA} \mathrm{Ac}_{1 \mathrm{c}}$ and VIM-HbA $\mathrm{A}_{1 \mathrm{c}}$. 
Data were evaluated and analysed using the SPSS 22.2 statistical software package and statistical significance was set at $p<0.05$. The specific statistical study carried out and the specific type of tests applied depended on the data obtained and their distribution. Descriptive statistical data determined the mean, standard deviation, minimum and maximum values Student's t-test was applied for independent samples. The inferential analysis was carried out through the creation of contingency tables, and the chi-squared test for qualitative variables. In cases where the reliability of this test was not guaranteed, we used Fisher's exact test. The two proportions in paired samples were compared using the McNemar test. The different time-dependent variables were compared to know their influence on the development of DR and MA by applying survival analysis using the Cox Proportional Hazards regression model.

\section{Results}

\subsection{Demographic Variables of Sample Size}

From 2007 to 2019, 366 T1DM patients were studied. Sample characteristics at the end of the study were as follows: current age $=35.20 \pm 10.03$ years, $193=$ males $(52.7 \%)$ and $173=$ females $(47.3 \%)$.

A total of 106 patients developed DR (29\%) and 73 MA (19.9\%). Overt diabetic nephropathy, by our definition, affected only five patients $(1.36 \%)$, and with such a small number of patients we did not carry out any statistical analysis.

By DR classification at the end of the study, we observed 70 patients (19.1\%) with mild DR, 20 patients (5.5\%) with moderate DR, eight patients $(2.2 \%)$ with severe DR and five patients $(1.4 \%)$ with proliferative DR. Table 1 shows the differences in the other parameters between groups and their significant values.

Table 1. Univariate study of diabetic retinopathy.

\begin{tabular}{|c|c|c|c|}
\hline Variable & $\begin{array}{l}\text { Without Diabetic } \\
\text { Retinopathy }\end{array}$ & $\begin{array}{l}\text { With Diabetic } \\
\text { Retinopathy }\end{array}$ & Significance \\
\hline Current age (years) & $35.87 \pm 10.22$ & $42.47 \pm 8.76$ & $p=0.026$ \\
\hline Male (\%) & $134(51.53)$ & $59(55.66)$ & $p=0.181$ \\
\hline Arterial hypertension (\%) & $13(3.55)$ & $27(21.58)$ & $p<0.001$ \\
\hline DM duration (years) & $15.17 \pm 8.3$ & $20.92 \pm 9.51$ & $p=0.034$ \\
\hline LDL cholesterol (mg/dL) & $101.33 \pm 27.71$ & $103.83 \pm 25.48$ & $p=0.674$ \\
\hline HDL cholesterol (mg/dL) & $75.27 \pm 18.04$ & $60.9 \pm 18.93$ & $p=0.386$ \\
\hline Triglycerides (mg/dL) & $108.73 \pm 14.25$ & $104.02 \pm 15.35$ & $p=0.213$ \\
\hline Microalbuminuria (mg/g) & $17.49 \pm 11.26$ & $31.15 \pm 14.27$ & $p=0.151$ \\
\hline $\mathrm{eGFR}\left(\mathrm{mL} / \mathrm{min} / 1.73 \mathrm{~m}^{2}\right)$ & $106.75 \pm 15.77$ & $96.11 \pm 18.67$ & $p=0.003$ \\
\hline $\begin{array}{c}\text { Mean-HbA } 1 \mathrm{c} \\
(\%) \\
\mathrm{mmol} / \mathrm{mol}\end{array}$ & $\begin{array}{c}7.56 \pm 0.88 \\
59.12 \pm 13.87\end{array}$ & $\begin{array}{c}8.86 \pm 1.44 \\
73.33 \pm 7.75\end{array}$ & $p<0.001$ \\
\hline \multicolumn{4}{|c|}{ Variability $\mathrm{HbA1c}$ data } \\
\hline $\mathrm{SD}-\mathrm{HbA}_{1 \mathrm{c}}$ & $0.45 \pm 0.36$ & $1.18 \pm 0.67$ & $p<0.001$ \\
\hline $\mathrm{CV}-\mathrm{HbA} \mathrm{A}_{1 \mathrm{c}}$ & $0.058 \pm 0.047$ & $0.112 \pm 0.079$ & $p<0.001$ \\
\hline ARV-HbA $\mathrm{A}_{1 \mathrm{c}}$ & $0.78 \pm 0.59$ & $2.09 \pm 0.98$ & $p<0.001$ \\
\hline VIM-HbA $1 \mathrm{c}$ & $0.38 \pm 0.07$ & $0.41 \pm 0.06$ & $p=0.037$ \\
\hline
\end{tabular}

\subsection{Univariate Analysis of Diabetic Retinopathy}

Table 1 shows the univariate analysis, in which current age, arterial hypertension, DM duration, eGFR and mean- $\mathrm{HbA}_{1 \mathrm{c}}$ were significant risk factors. For variability, all studied 
parameters (SD-HbA $A_{1 c}, C V-H b A_{1 c}, A R V-H b A_{1 c}$ and VIM-HbA $A_{1 c}$ ) were significant, despite $\mathrm{VIM}-\mathrm{Hb} \mathrm{A}_{1 \mathrm{c}}$ being the only one with significance above 0.001 and with a value of $p=0.037$.

\subsection{Univariate Study of the Severity of Diabetic Retinopathy}

The univariate analysis shows significant differences in DR for current age $(p<0.001)$,

DM duration $(p<0.001)$, arterial hypertension $(p<0.001)$, and mean $\mathrm{HbA}_{1 \mathrm{c}}(p<0.001)$.

For $\mathrm{HbA}_{1 \mathrm{c}}$ variability, all four studied parameters were significant: SD-HbA $1 \mathrm{c}(p<0.001)$, VC-HbA $1 \mathrm{c}(p<0.001)$, VIM-HbA $1 \mathrm{c}(p<0.001)$, and ARV-HbA $1 \mathrm{c}(p<0.001)$ (Table 2$)$.

Table 2. Differences in severity of diabetic retinopathy with significant variables and microalbuminuria.

\begin{tabular}{|c|c|c|c|c|c|}
\hline & Mild DR & Moderate DR & Severe DR & Proliferative DR & Significance \\
\hline Current age (years) & $37.86 \pm 10.19$ & $42.55 \pm 9.32$ & $42.56 \pm 8.92$ & $46.01 \pm 7.91$ & $p<0.001$ \\
\hline Arterial hypertension (\%) & $17(24.28)$ & $6(30)$ & $4(50)$ & $4(80)$ & $p<0.001$ \\
\hline Diabetes duration (years) & $17.24 \pm 8.26$ & $18.24 \pm 8.75$ & $20.62 \pm 9.6$ & $27.8 \pm 8.37$ & $p<0.001$ \\
\hline $\begin{array}{c}\text { Mean-HbA } 1 \mathrm{c} \\
(\%) \\
(\mathrm{mmol} / \mathrm{mol})\end{array}$ & $\begin{array}{c}8.68 \pm 1.43 \\
71.36 \pm 7.86\end{array}$ & $\begin{array}{c}9.16 \pm 1.22 \\
76.61 \pm 10.16\end{array}$ & $\begin{array}{c}9.86 \pm 1.25 \\
84.26 \pm 9.83\end{array}$ & $\begin{array}{l}10.36 \pm 1.45 \\
89.72 \pm 7.65\end{array}$ & $p<0.001$ \\
\hline \multicolumn{6}{|c|}{ Study of variability } \\
\hline $\mathrm{SD}-\mathrm{HbA}_{1 \mathrm{c}}$ & $1.05 \pm 0.5$ & $1.37 \pm 0.79$ & $1.82 \pm 0.85$ & $1.91 \pm 1.18$ & $p<0.001$ \\
\hline $\mathrm{CV}-\mathrm{HbA}_{1 \mathrm{c}}$ & $0.101 \pm 0.069$ & $0.126 \pm 0.087$ & $0.175 \pm 0.107$ & $0.186 \pm 0.117$ & $p<0.001$ \\
\hline VIM-HbA $1 \mathrm{c}$ & $0.40 \pm 0.06$ & $0.41 \pm 0.04$ & $0.47 \pm 0.05$ & $0.51 \pm 0.04$ & $p<0.001$ \\
\hline $\mathrm{ARV}-\mathrm{HbA}_{1 \mathrm{c}}$ & $1.86 \pm 0.92$ & $2.51 \pm 0.92$ & $2.75 \pm 1.12$ & $2.66 \pm 1.04$ & $p<0.001$ \\
\hline \multicolumn{6}{|c|}{ Study of microalbuminuria } \\
\hline Microalbuminuria (mg/g) & $37.2 \pm 19.9$ & $16.8 \pm 18.11$ & $18.23 \pm 17.62$ & $37.92 \pm 17.11$ & $p=0.739$ \\
\hline
\end{tabular}

\subsection{Microalbuminuria Univariate Analysis}

Table 3 shows the univaritate analysis, in which current age, arterial hypertension, DM

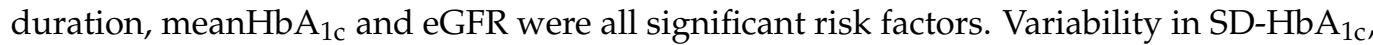
$\mathrm{CV}-\mathrm{HbA}_{1 \mathrm{c}}$ and $\mathrm{ARV}-\mathrm{HbA}_{1 \mathrm{c}}$ was significant, but VIM-HbA $\mathrm{Ac}_{1 \mathrm{c}}$ was not significant at $p=0.750$. The relationship between MA and DR in this study are significant at a $p=0.003$, despite the previous analysis (Table 3 ) for the presence of DR of microalbuminuria not being significant. At this point, we should explain that the statistical study was different in that we used chi-squared (a qualitative test) for MA and we used Student's t-test (a quantitative test) for DR.

Table 3. Univariate study of microalbuminuria.

\begin{tabular}{cccc}
\hline Variable & $\begin{array}{c}\text { Without } \\
\text { Microalbuminuria }\end{array}$ & $\begin{array}{c}\text { With } \\
\text { Microalbuminuria }\end{array}$ & Significance \\
\hline Current age (years) & $36.6 \pm 10.25$ & $41.58 \pm 8.76$ & $p=0.034$ \\
\hline Male (\%) & $152(51.87)$ & $41(56.16)$ & $p=0.102$ \\
\hline Arterial hypertension $(\%)$ & $25(8.53)$ & $15(20.54)$ & $p<0.001$ \\
\hline DM duration $($ years) & $15.96 \pm 8.76$ & $20.41 \pm 9.18$ & $p=0.029$ \\
\hline LDL cholesterol $(\mathrm{mg} / \mathrm{dL})$ & $102.23 \pm 26.55$ & $101.32 \pm 29.26$ & $p=0.552$ \\
\hline HDL cholesterol $(\mathrm{mg} / \mathrm{dL})$ & $58.69 \pm 17.04$ & $61.36 \pm 19.13$ & $p=0.255$ \\
\hline Triglycerides $(\mathrm{mg} / \mathrm{dL})$ & $106.53 \pm 13.68$ & $110.73 \pm 16.27$ & $p=0.509$ \\
\hline eGFR $\left(\mathrm{mL} / \mathrm{min} / 1.73 \mathrm{~m}{ }^{2}\right)$ & $105.33 \pm 16.16$ & $97.16 \pm 20.16$ & $p=0.001$ \\
\hline Diabetic retinopathy $(\%)$ & $50(17.1)$ & $56(76.7)$ & $p=0.003$ \\
\hline
\end{tabular}


Table 3. Cont.

\begin{tabular}{|c|c|c|c|}
\hline Variable & $\begin{array}{c}\text { Without } \\
\text { Microalbuminuria }\end{array}$ & $\begin{array}{c}\text { With } \\
\text { Microalbuminuria }\end{array}$ & Significance \\
\hline $\begin{array}{c}\text { Mean-HbA } 1 \mathrm{c} \\
(\%) \\
\mathrm{mmol} / \mathrm{mol}\end{array}$ & $\begin{array}{c}7.76 \pm 1.13 \\
61.85 \pm 10.92\end{array}$ & $\begin{array}{c}8.79 \pm 1.36 \\
66.01 \pm 8.63\end{array}$ & $p=0.003$ \\
\hline \multicolumn{4}{|c|}{ Variability $\mathrm{HbA1c}$ data } \\
\hline $\mathrm{SD}-\mathrm{HbA}_{1 \mathrm{c}}$ & $0.54 \pm 0.43$ & $1.15 \pm 0.8$ & $p<0.001$ \\
\hline $\mathrm{CV}-\mathrm{HbA}_{1 \mathrm{c}}$ & $0.062 \pm 0.048$ & $0.117 \pm 0.091$ & $p<0.001$ \\
\hline ARV-HbA $1 \mathrm{c}$ & $0.95 \pm 0.74$ & $2.01 \pm 1.13$ & $p<0.001$ \\
\hline VIM-HbA $1 c$ & $0.38 \pm 0.07$ & $0.41 \pm 0.07$ & $p=0.750$ \\
\hline
\end{tabular}

\subsection{Multivariate Study of Diabetic Retinopathy}

For the survival study of DR, we used the Cox Proportional Hazards model that determines which variables are significant in the development of DR with the duration of DM as a time variable. Our results determined that age at the end of the study and the metabolic control of $\mathrm{DM}$ measured by mean- $\mathrm{HbA}_{1 \mathrm{c}}$ values were significant for $\mathrm{DR}$, and the variability parameters of $\mathrm{SD}-\mathrm{HbA}_{1 \mathrm{c}} \mathrm{A} 1 \mathrm{c}$ and $\mathrm{ARV}-\mathrm{HbA}_{1 \mathrm{c}}$ were significant (Table 4).

Table 4. Survival study of diabetic retinopathy.

\begin{tabular}{|c|c|c|}
\hline \multicolumn{3}{|c|}{ Diabetic Retinopathy } \\
\hline Variable & Hazard Ratio (95\% CI) & Significance \\
\hline Current age (years) & $1.955(1.57-2.528)$ & $p<0.001$ \\
\hline Arterial hypertension & $1.149(0.646-2.044)$ & $p=0.635$ \\
\hline $\mathrm{eGFR}\left(\mathrm{mL} / \mathrm{min} / 1.73 \mathrm{~m}^{2}\right)$ & $0.999(0.988-1.011)$ & $p=0.913$ \\
\hline Mean-HbA $1 \mathrm{c}$ & 3.502 (1.081-11.349) & $p=0.037$ \\
\hline $\mathrm{SD}-\mathrm{HbA}_{1 \mathrm{c}}$ & $1.966(1.125-3.434)$ & $p=0.018$ \\
\hline $\mathrm{CV}-\mathrm{Hb} \mathrm{A}_{1 \mathrm{c}}$ & $1.448(0.897-2.456)$ & $p=0.169$ \\
\hline $\mathrm{ARV} \mathrm{HbA}_{1 \mathrm{c}}$ & $2.171(1.326-3.555)$ & $p=0.002$ \\
\hline $\mathrm{VIM}-\mathrm{HbA}_{1 \mathrm{c}}$ & $0.672(0.397-1.130)$ & $p=0.134$ \\
\hline \multicolumn{3}{|c|}{ Diabetic retinopathy severity * } \\
\hline Variable & Hazard ratio $(95 \% \mathrm{CI})$ & Significance \\
\hline Current age (years) & $1.159(1.057-2.991)$ & $p=0.003$ \\
\hline Arterial hypertension & $1.479(0.842-2.597)$ & $p=0.173$ \\
\hline $\mathrm{eGFR}\left(\mathrm{mL} / \mathrm{min} / 1.73 \mathrm{~m}^{2}\right)$ & $1.001(0.989-1.012)$ & $p=0.928$ \\
\hline Mean- $\mathrm{HbA}_{1 \mathrm{c}}$ & $1.321(1.108-1.575)$ & $p=0.002$ \\
\hline $\mathrm{SD}-\mathrm{HbA}_{1 \mathrm{c}}$ & $1.744(1.089-3.385)$ & $p<0.001$ \\
\hline $\mathrm{CV}-\mathrm{Hb} \mathrm{A}_{1 \mathrm{c}}$ & $1.390(1.076-1.796)$ & $p=0.012$ \\
\hline ARV- $\mathrm{HbA}_{1 \mathrm{c}}$ & $0.514(0.002-1.893)$ & $p=0.809$ \\
\hline VIM-HbA $1 \mathrm{c}$ & $0.100(0.005-1.912)$ & $p=0.126$ \\
\hline
\end{tabular}


Table 4. Cont.

\begin{tabular}{ccc}
\hline & Diabetic Retinopathy & \\
\hline & Microalbuminuria & \\
\hline Variable & Hazard ratio $(95 \% \mathrm{CI})$ & Significance \\
\hline Current age (years) & $1.957(1.357-2.787)$ & $p=0.008$ \\
\hline Arterial hypertension & $1.049(0.412-1.735)$ & $p=0.892$ \\
\hline eGFR $\left(\mathrm{mL} / \mathrm{min} / 1.73 \mathrm{~m}^{2}\right)$ & $1.002(0.760-1.014)$ & $p=0.734$ \\
\hline Mean-HbA $1 \mathrm{c}$ & $1.472(1.029-1.572)$ & $p=0.026$ \\
\hline $\mathrm{SD}-\mathrm{HbA}_{1 \mathrm{c}}$ & $1.377(1.006-3.554)$ & $p=0.028$ \\
\hline $\mathrm{CV}-\mathrm{HbA}_{1 \mathrm{c}}$ & $1.025(0.461-2.278)$ & $p=0.952$ \\
\hline $\mathrm{ARV} \mathrm{HbA}$ & $1.179(1.020-1.864)$ & $p=0.036$ \\
\hline $\mathrm{VIM}_{1 \mathrm{HbA}}$ & $0.264(0.208-4.252)$ & $p=0.449$ \\
\hline
\end{tabular}

Diabetic retinopathy severity * $=$ moderate DR + severe DR + proliferative DR.

\subsection{Multivariate Study of Severity of Diabetic Retinopathy}

Applying the Cox survival analysis for the severity of DR, only current age (HR $=1.159$, $p=0.003)$ and mean- $\mathrm{HbA}_{1 \mathrm{c}}(\mathrm{HR}=1.321, p=0.002)$ were significant and for the $\mathrm{HbA}_{1 \mathrm{c}}$ variability study, the $\mathrm{SD}-\mathrm{HbA}_{1 \mathrm{c}}$ with $\mathrm{HR}=1.514 p<0.001$ and $\mathrm{CV}-\mathrm{HbA}_{1 \mathrm{c}}$ with $\mathrm{HR}=1.290$, $p=0.012$ were significant.

The MA study does not show any link with severity of DR in the Student's analysis $(p=0.739)$ (Table 4$)$.

\subsection{Survival Analysis of Microalbuminuria}

For the survival study of MA using the Cox Proportional Hazards model, our results were: current age $(\mathrm{HR}=1.957, p=0.008)$ and mean- $\mathrm{HbA}_{1 \mathrm{c}}(\mathrm{HR}=1.472, p=0.026)$, significant for MA.

In the $\mathrm{HbA} 1 \mathrm{c}$ variability study, the SD-HbA $1 \mathrm{c}(\mathrm{HR} 1.377, p=0.028)$ and $\mathrm{ARV}-\mathrm{HbA}_{1 \mathrm{c}}$ (HR 1.179, $p=0.036$ ) were significant (Table 4).

\section{Discussion}

The results of the present study show that current age is a risk factor in the development of DR and MA, which might be due to the duration of DM, a well-known risk factor in the development of microangiopathy. In addition, other parameters such as arterial hypertension, eGFR measured through CKD-EPI and the mean of $\mathrm{HbA} 1 \mathrm{c}$ levels were all significant for both forms of microangiopathy. All these parameters are well-known risk factors for DR and developing of MA, as the DCCT and the EDIC also reported following their extensive studies [27]. Among the different parameters that measure the importance of variability in $\mathrm{HbA}_{1 \mathrm{c}}$ in microangiopathy, the univariate statistical analysis determined that $\mathrm{SD}-\mathrm{HbA}_{1 \mathrm{c}}, \mathrm{CV}-\mathrm{HbA}_{1 \mathrm{c}}, \mathrm{VIM}-\mathrm{HbA}_{1 \mathrm{c}}$ and $\mathrm{ARV}-\mathrm{HbA}_{1 \mathrm{c}}$ were all significant for $\mathrm{DR}$ and MA. However, the results changed following adjustments for other significant variables, such as current age, arterial hypertension, eGFR and mean- $\mathrm{HbA}_{1 \mathrm{c}}$. For developing DR, only SD-HbA $\mathrm{Ac}_{1 \mathrm{c}}(\mathrm{HR} 1.966, p=0.018)$ and ARV-HbA $1 \mathrm{c}(2.171, p=0.002)$ were significant. Moreover, for microalbuminuria, only SD-HbA $\mathrm{H}_{1 \mathrm{c}}(\mathrm{HR} 1.377, p=0.0128)$ and ARV-HbA $\mathrm{H}_{\mathrm{c}}(1.179$, $p=0.036$ ) were significant. Only for DR severity did the $\mathrm{CV}-\mathrm{HbA}_{1 \mathrm{c}}$ become significant ( $\mathrm{HR}=1.290, p=0.012)$. VIM-Hb $\mathrm{A}_{1 \mathrm{c}}$ was not significant for DR, MA or DR severity.

If we compare our results to other studies on $\mathrm{HbA}_{1 \mathrm{c}}$ variability, there have been three that have studied only DR development $[13,15,16]$, three that have studied only nephropathy [11,12,14], and one that has studied both forms of microangiopathy [10]. The most important study was by Herman et al. [15], a retrospective study focusing on the $\mathrm{CV}-\mathrm{HbA}_{1 \mathrm{c}}$ of over $35,891 \mathrm{~T} 1 \mathrm{DM}$ patients. Variability in $\mathrm{HbA}_{1 \mathrm{c}}$ was reported as a risk factor for DR, independent of metabolic control, with HR 1.11 at ten years of DM duration. 
The other two studies on $\mathrm{HbA}_{1 \mathrm{c}}$ variability and DR both focused on severe forms of DR. Hietala et al. [13] was a retrospective study over a 5.5-year follow-up with a sample size of 2029 T1DM patients, which reported a relationship between $\mathrm{CV}-\mathrm{Hb} \mathrm{A}_{1 \mathrm{c}}$ and laser treatments of patients. The second study, by Schreuer et al. [16], was a cross-sectional study on 415 T1DM patients, which also demonstrated a relationship between $\mathrm{CV}-\mathrm{HbA}_{1 \mathrm{c}}$ and patients who develop sight-threatening DR (HR 1.054). The present study did not demonstrate any relationship between $\mathrm{CV}-\mathrm{HbA}_{1 \mathrm{c}}$ and $\mathrm{DR}$ development, but a positive relationship with severe DR, similar to the Hietala and Schreuer studies. Herman adjusted the results for age and gender, and we adjusted our results for DM duration, renal status (using eGFR and MA) and other parameters, such as arterial hypertension and lipid profile, differences which might explain our results. Another group of studies that we compare are those on MA and diabetic nephropathy. The first study is by Marcoveccchio et al. [12], who found that 438 patients from a sample of 1232 patients with DM1 had a positive relationship between $\mathrm{SD}-\mathrm{HbA}_{1 \mathrm{c}}$ and $\mathrm{MA}$ with $\mathrm{HR}$ 1.04, and also a positive relationship between $\mathrm{SD}-\mathrm{HbA}_{1 \mathrm{c}}$ and MA with $\mathrm{HR}$ 1.31. The second study was by Nazim et al. [14], a cross-sectional study that also found a positive relationship between MA and SD-HbA $1 \mathrm{c}$ (HR 1.04), and a third study by Waden et al. [11], a prospective 5.7-year follow-up of 2107 T1DM patients again found a positive relationship between $\mathrm{SD}-\mathrm{HbA}_{1 \mathrm{c}}$ and a progression in renal status (HR 1.92).

The last study to discuss is by Kilpatrick et al. [10], who applied data from the DCCT to 1441 T1DM patients, checking whether long-term variability had any effect on the development of DR. Their results showed that long-term variability, measured by the SD$\mathrm{HbA}_{1 \mathrm{c}}$, increased the risk of developing both DR (HR 2.26), and nephropathy (SD-HbA $1 \mathrm{c}$ HR 1.86).

Our results are similar to those published in the literature, with some variations. We found a positive relationship between $\mathrm{SD}-\mathrm{HbA}_{1 \mathrm{c}}$ and $\mathrm{DR}$ development and microalbuminuria. The $\mathrm{CV}-\mathrm{HbA}_{1 \mathrm{c}}$ parameter is only significant for severe $\mathrm{DR}$, in agreement with Hietala and Screuer but contradicting Herman. Regarding the other studied parameters, VIM- $-\mathrm{HbA}_{1 \mathrm{c}}$ and ARV-HbA $\mathrm{Ac}_{1 \mathrm{c}}$, there have been no published results for T1DM patients, but in T2DM, reported by Takao et al. [28], independent of the mean (VIM) of $\mathrm{HbA}_{1 \mathrm{c}}$ and of systolic blood pressure the variation can predict the appearance of DR and MA. In the present study this parameter was not significant for DR or MA. The VIM is used in the control of arterial hypertension proving its effectiveness for SBP variability [17], but in current study we studied the association of arterial hypertension and not SBP values, this may be the cause of the lack of statistical significance in our study.

We can conclude that VIM was not important for detecting $\mathrm{HbA}_{1 \mathrm{c}}$ variability in T1DM patients or elucidating its relationship with DR development.

Finally, ARV-HbA $\mathrm{Ac}_{1 \mathrm{c}}$ is a parameter that has not been studied in T1DM patients. It is closely related to mean- $\mathrm{HbA}_{1 \mathrm{c}}$, which is a well-known risk factor for DR and MA; therefore, we can conclude that $\mathrm{AR}-\mathrm{HbA}_{1 \mathrm{c}}$ might help us to determine $\mathrm{DR}$ development. Regarding the relationship between both microangiopathies, MA and DR, our study group has published some articles previously $[29,30]$ with similar results to the present study. $\mathrm{MA}$ is not a risk factor for DR development but the presence of DR can be a marker of the presence of MA in T1DM patients.

This study has some limitations. It is retrospective and the sample of T1DM patients is small, with only 366 patients who met the inclusion criteria; therefore, an extrapolation of our results to other populations still needs to be demonstrated. Another limitation is that it only takes account of $\mathrm{HbA}_{1 \mathrm{c}}$-variability patients with a minimum of eight previous $\mathrm{HbA}_{1 \mathrm{c}}$ values. Therefore, we need more studies with a longer follow-up period in order to obtain more useful data for clinical practice.

The strengths of our study are, firstly, that the sample size is in fact highly representative of our population as a whole because patients were recruited from our own T1DM screening programme, and secondly, we have included all the risk variables that might influence DR or MA. 


\section{Conclusions}

In conclusion, long-term glycaemic variability emerges as a target that needs to be corrected in order to avoid complications in Diabetes Mellitus, such as diabetic retinopathy. The standard deviation of $\mathrm{HbA}_{1 \mathrm{c}}$ and average real variability of $\mathrm{HbA}_{1 \mathrm{c}}$ are better related to diabetic retinopathy and microalbuminuria and it will be a possible variable for detecting patients at risk of developing microangiopathy. The coefficient of variation of $\mathrm{HbA}_{1 \mathrm{c}}$ was related to sever DR and we have not demonstrated any significance of the variation independent of the mean $\left(\mathrm{VIM}-\mathrm{HbA}_{1 \mathrm{c}}\right)$ with DR nor MA development. More studies with stronger evidence and a longer follow-up period are essential if we are to obtain better data for clinical practice.

Author Contributions: P.R.-A. contributed to the study conception and design, collected research data, reviewed the statistical analysis, wrote the discussion, and edited the manuscript, contributing to the final approval of the version sent for publication. R.N.-G. contributed to the study conception and design, contributed to ophthalmological data collection, diagnosed diabetic retinopathy and nephropathy, carried out the laboratory procedures, wrote the discussion, and constructed a critical review, contributing to the final approval of the version sent for publication. A.F. Contributed to the study conception and design, collected research data, reviewed the statistical analysis, wrote the discussion, and edited the manuscript, contributing to the final approval of the version sent for publication. A.V. Contributed to the study design and the statistical analysis, interpreted the research data, constructed a critical review and reviewed the translation, contributing to the final approval of the version sent for publication. A.M. Contributed to the study design and the statistical analysis, interpreted research data and contributed to the interpretation of the study findings, contributing to the final approval of the version sent for publication. M.B.-B. contributed to the ophthalmological data collection. He carried out and read the retinographies, and OCT procedures and interpreted the research data, contributing to the final approval of the version sent for publication. All authors have read and agreed to the published version of the manuscript.

Funding: The study was approved and supported by research project grants PI12/01535 June 2013, and PI15/01150 July 2015, PI18/00169 July 2018 (Instituto de Salud Carlos III (IISCIII) of Spain), and FEDER funds.

Institutional Review Board Statement: The study was conducted according to the guidelines of the Declaration of Helsinki and approved by the Institutional ethics committee (CEIM Tarragona) with the approval number: 13-01-31/proj6, Institut de Investigacions Sanitaries Pere Virgili (IISPV).

Informed Consent Statement: Informed consent was obtained from all subjects involved in the study. When patients were included, they were told about the objective of the study before signing the consent forms. Recruitment was conducted according to the screening programme protocol that uses a systematic recruitment technique. The results will be disseminated to participants at the end of the study.

Data Availability Statement: The database used and analysed is available from the corresponding author on research request.

Acknowledgments: We thank all paediatricians, general practitioners and endocrinologists in our area who helped us to implement the new screening system using the non-mydriatic fundus camera, and our camera technicians for their work and interest in the diabetes screening. We thank all the patients as participants in the present study. We also thank Phil Hoddy for his language assistance and for editing and correcting the English text.

Conflicts of Interest: The authors declare no conflict of interest.

\section{References}

1. Shaw, J.E.; Sicree, R.A.; Zimmet, P.Z. Global estimates of the prevalence of diabetes for 2010 and 2030. Diabetes Res. Clin. Pract. 2010, 87, 4-14. [CrossRef]

2. Atlas de la Diabetes de la FID, Séptima Edición. International Diabetes Federation, IDF 2015. ISBN 978-2-930229-81-2. Available online: www.idf.org/e-library/epidemiology-research/diabetes-atlas.html2020 (accessed on 2 May 2020).

3. American Diabetes Assoiciation. Classification and Diagnosis of Diabetes, Standards of Medical Care in Diabetes-2018. Diabetes Care 2018, 41, S13-S27. [CrossRef] [PubMed] 
4. Flaxman, S.R.; Bourne, R.R.A.; Resnikoff, S.; Ackland, P.; Braithwaite, T.; Cicinelli, M.V.; Das, A.; Jonas, J.B.; Keeffe, J.; Kempen, J.H.; et al. Vision Loss Expert Group of the Global Burden of Disease Study. Global causes of blindness and distance vision impairment 1990-2020, a systematic review and meta-analysis. Lancet Glob. Health 2017, 5, e1221-e1234. [CrossRef] [PubMed]

5. Yau, J.W.; Rogers, S.L.; Kawasaki, R.; Lamoureux, E.L.; Kowalski, J.W.; Bek, T.; Chen, S.-J.; Dekker, J.M.; Fletcher, A.; Grauslund, J.; et al. Meta-Analysis for Eye Disease (META-EYE) Study Group. Global prevalence and major risk factors of diabetic retinopathy. Diabetes Care 2012, 35, 556-564. [CrossRef] [PubMed]

6. Rodríguez-Segade, S.; Rodríguez, J.; López, J.M.; Casanueva, F.F.; Camiña, F. Intrapersonal HbA1c variability and the risk of progression of nephropathy in patients with Type 2 diabetes. Diabet. Med. 2012, 29, 1562-1566. [CrossRef] [PubMed]

7. Kilpatrick, E.; Rigby, A.S.; Atkin, S.L. The effect of glucose variability on the risk of microvascular complications in type 1 diabetes. Diabetes Care 2006, 29, 1486-1490. [CrossRef]

8. Bragd, J.; Adamson, U.; Bäcklund, L.B.; Lins, P.; Moberg, E.; Oskarsson, P. Can glycaemic variability, as calculated from blood glucose self- monitoring, predict the development of complications in type1 diabetes over a decade? Diabetes Metab. 2008, 34, 612-616. [CrossRef]

9. Sartore, G.; Chilelli, N.C.; Burlina, S.; Lapolla, A. Association between glucose variability as assessed by continuous glucose monitoring (CGM) and diabetic retinopathy in type 1 and type 2 diabetes. Acta Diabetol. 2013, 50, 437-442. [CrossRef]

10. Kilpatrick, E.S.; Rigby, A.S.; Atkin, S.L. A1C variability and the risk of microvascular complicationsin type 1 diabetes, data from the Diabetes Control and Complications Trial. Diabetes Care 2008, 31, 2198-2202. [CrossRef]

11. Waden, J.; Forsblom, C.; Thorn, L.M.; Gordin, D.; Saraheimo, M.; Groop, P.H. Finnish Diabetic Nephropathy Study Group. A1C variability predicts incident cardiovascular events, microalbuminuria, and overt diabetic nephropathy in patients with type 1 diabetes. Diabetes 2009, 58, 2649-2655. [CrossRef]

12. Marcovecchio, M.L.; Dalton, R.N.; Chiarelli, F.; Dunger, P.D. A1C variability as an independent risk factor for microalbuminuria in young peoplewith type 1 diabetes. Diabetes Care 2011, 34, 1011-1013. [CrossRef]

13. Hietala, K.; Wadén, J.; Forsblom, C.; Harjutsalo, V.; Kytö, J.; Summanen, P.; Groop, P.-H.; FinnDiane Study Group. HbA1c variability is associated with an increased risk of retinopathy requiring laser treatment in type 1 diabetes. Diabetologia 2013, 56, 737-745. [CrossRef] [PubMed]

14. Nazim, J.; Fendler, W.; Starzyk, J. Metabolic control and its variability are major risk factors for microalbuminuria in children with type 1 diabetes. Endokrynol. Pol. 2014, 65, 83-89. [CrossRef]

15. Hermann, J.M.; Hammes, H.-P.; Rami-Merhar, B.; Rosenbauer, J.; Schütt, M.; Siegel, E.; Holl, R.W.; DPV Initiative the German BMBF Competence Network Diabetes Mellitus. HbA1c variability as an independent risk factor for diabetic retinopathy in type 1 diabetes, A german/austrian multicenter analysis on 35,891 patients. PLoS ONE 2014, 9, e91137. [CrossRef] [PubMed]

16. Schreur, V.; van Asten, F.; Ng, H.; Weeda, J.; Groenewoud, J.M.M.; Tack, C.J.; Hoyng, C.B.; De Jong, E.K.; Klaver, C.C.; Klevering, B.J. Risk factors for development and progression of diabetic retinopathy in Dutch patients with type 1 diabetes mellitus. Acta Ophthalmol. 2018, 96, 459-464. [CrossRef] [PubMed]

17. Rothwell, P.M.; Howard, S.C.; Dolan, E.; O’Brien, E.; Dobson, J.E.; Dahlöf, B.; Sever, P.S.; Poulter, N.R. Prognostic significance of visit-to-visit variability, maximum systolic blood pressure, and episodic hypertension. Lancet 2010, 375, 895-905. [CrossRef]

18. Mena, L.; Pintos, S.; Queipo, N.V.; Aizpurua, J.A.; Maestre, G.; Sulbaran, T. A reliable index for the prognostic significance of blood pressure variability. J. Hypertens. 2005, 23, 505-511. [CrossRef]

19. Romero-Aroca, P.; De La Riva-Fernandez, S.; Valls-Mateu, A.; Àlamo, R.; Moreno-Ribas, A.; Soler, N. Changes observed in diabetic retinopathy. Eight year follow up of a Spanish population. Br. J. Ophthalmol. 2016, 100, 1366-1371. [CrossRef] [PubMed]

20. Romero-Aroca, P.; Navarro-Gil, R.; Valls-Mateu, A.; Àlamo, R.; Moreno-Ribas, A.; Soler, N. Differences in incidence of diabetic retinopathy between type 1 and 2 diabetes mellitus, a nine-year follow-up study. Br. J. Ophthalmol. 2017, 101, 1346-1351. [CrossRef]

21. Cavallerano, J.D.; Aiello, L.P.; Cavallerano, A.A.; Katalinic, P.; Hock, K.; Kirby, R. Nonmydriatic digital imaging alternative for annual retinal examination in persons with previously documented no or mild diabetic retinopathy. Am. J. Ophthalmol. 2005, 140, 667-673. [CrossRef] [PubMed]

22. Wilkinson, C.P.; Ferris, F.L., III; Klein, R.E.; Lee, P.P.; Agardh, C.D.; Davis, M.; Dills, D.; Kampik, A.; Pararajasegaram, R.; Verdaguer, J.T. Proposed international clinical diabetic retinopathy and diabetic macular edema disease severity scales. Ophthalmology 2003, 110, 1677-1682. [CrossRef]

23. American Diabetes Association; European Association for the Study of Diabetes; International Federation of Clinical Chemistry and Laboratory Medicine; International Diabetes Federation. Consensus statement on the worldwide standardization of the HbA1c measurement. Diabetologia 2007, 50, 2042-2043. [CrossRef] [PubMed]

24. European Diabetes Policy Group. A desktop guide to type I (insulin-dependent) diabetes mellitus. 1998-1999. Guidelines for Diabetes care. Diabet. Med. 1999, 16, 253-266. [CrossRef]

25. American Diabetes Association. Glycemic targets, standards of medical care in diabetes 2020. Diabetes Care 2020, 43, S66-S76. [CrossRef]

26. Rothwell, P.M.; Howard, S.C.; Dolan, E.; O’Brien, E.; Dobson, J.E.; Dahlöf, B.; Poulter, N.R.; Sever, P.S. Effects of b blockers and calcium-channel blockers on within-individual variability in blood pressure and risk of stroke. Lancet Neurol. 2010, 9, 469-480. [CrossRef] 
27. Diabetes Control and Complications Trial (DCCT)/Epidemiology of Diabetes Interventions and Complications (EDIC) Research Group. Effect of intensive diabetes therapy on the progression of diabetic retinopathy in patients with type 1 diabetes, 18 years of follow-up in the DCCT/EDIC. Diabetes 2015, 64, 631-642. [CrossRef]

28. Takao, T.; Suka, M.; Yanagisawa, H.; Matsuyama, Y.; Iwamoto, Y. Predictive ability of visit-to-visit variability in HbA1c and systolic blood pressure for the development of microalbuminuria and retinopathy in people with type 2 diabetes. Diabetes Res. Clin. Pract. 2017, 128, 15-23. [CrossRef]

29. Romero-Aroca, P.; Baget-Bernaldiz, M.; Navarro-Gil, R.; Moreno-Ribas, A.; Valls-Mateu, A.; Àlamo, R.S.; La Puente, J.F.B.-D.; Mundet-Tuduri, X. Glomerular Filtration Rate and/or Ratio of Urine Albumin to Creatinine as Markers for Diabetic Retinopathy, A Ten-Year Follow-Up Study. J. Diabetes Res. 2018, 2018, 5637130. [CrossRef]

30. Romero-Aroca, P.; Baget-Bernaldiz, M.; Reyes-Torres, J.; Fernandez-Ballart, J.; Plana-Gil, N.; Mendez-Marin, I.; Ríos, A.P. Relationship between diabetic retinopathy, microalbuminuria and overt nephropathy, and twenty-year incidence follow-up of a sample of type 1 diabetic patients. J. Diabetes Complicat. 2012, 26, 506-512. [CrossRef] [PubMed] 